\title{
Scottish public libraries welcome Syrian new Scots: a transition from being a refugee to becoming an active part of the community.
}

\author{
MARTZOUKOU, $\mathrm{K}$.
}

This is a preprint of a chapter accepted for publication by Facet Publishing. This extract has been taken from the author's original manuscript and has not been edited. The definitive version of this piece may be found in GOLDSTEIN, S. (ed.) Informed societies: why information literacy matters for citizenship, participation and democracy. Facet, London. ISBN 9781783304226 , which can be purchased from http://www.facetpublishing.co.uk/title.php?id=304226. The author agrees not to update the preprint or replace it with the published version of the chapter. 


\section{Chapter 6}

\section{Scottish Public Libraries Welcome Syrian new Scots: a transition from being a refugee to becoming an active part of the community}

\section{Konstantina Martzoukou, Robert Gordon University Aberdeen}

8,635 words excluding references

\section{Introduction}

This chapter offers an overview of the information needs and experiences of Syrian refugees in Scotland, drawing from data collected as part of 'Lost in Information: Syrian new Scots' Information Literacy Way-finding practices', a research project which was funded by the CILIP Information Literacy Group (ILG) in the UK. The aim of the research was to explore the information needs of Syrian refugees, their habitual and adaptive information literacy practices and the barriers and enablers they encountered within their new socio-cultural setting via their interaction with people, tools and processes. The chapter begins by discussing the Scottish government strategy for welcoming Syrian refugees and by exploring the fundamental everyday life needs of Syrian refugees during the first few months after relocating to Scotland. These included learning English, reuniting with family members, securing employment and achieving financial security. In view of this focus and based on the emphasis of this book on the role of information for democracy, civic rights and participation, the chapter discusses Scottish public libraries' vision of supporting vulnerable communities and helping to build capacity for the active contribution of refugees to their host society, enabling information support and activities that create a sense of belonging for all. The chapter concludes with presenting a number of Scottish public libraries' case studies from the Northeast of Scotland, showcasing how they have responded to the social needs of Syrian refugees, offering information related services, organising specific integration related activities and programmes and making library space a place for learning. Public libraries in Scotland have developed impactful work to support Syrian refugees in their local communities, which could be further empowered by creating close partnerships with refugee support services and organisations. There is potential for public libraries to make a sustainable difference to the lives of Syrian new Scots and the communities which have welcomed them supporting civic participation and inclusion for all.

\section{Syrian new Scots: Syrian refugees in Scotland}

On 7 September 2015, the UK Prime Minister (at that time David Cameron) announced an expansion of the existing 'Syrian Vulnerable Persons Relocation Scheme (VPRS)' to resettle over five years (by 2020) an additional 20,000 Syrians drawn from established refugee camps. A second resettlement route to the UK was also announced on 21 April 2016 for 3,000 vulnerable 'children at risk' (as defined by the United Nations High Commissioner for Refugees UNHCR) from the Middle East and North Africa (MENA) region. This broad category includes unaccompanied, separated from their families and vulnerable children (e.g. child carers and those at risk of child labour, child marriage or other forms of neglect, abuse or exploitation) (Brokenshire, 2016).

Following the UK government's announcement of the arrival of Syrian refugees, the Chartered Institute of Library and Information Professionals (CILIP) outlined the important role of public and school libraries in the country, as key sources of information, as welcoming places and as access points to information about refugees, helping to inform local communities about the 
realities of forced migration (Vincent, 2015). In addition, on 25 September 2015, The Society of Chief Librarians (which leads and manages public libraries in England, Wales and Northern Ireland and is made up of the head of service of every library authority) and ASCEL (the Association of Senior Children's and Education Librarians, which is national network of senior managers in Children's Public and Schools Library Services) produced a statement setting out the role that public libraries play in welcoming refugees. A number of areas where library leaders across England and Wales expressed their commitment to offer support included the following areas:

- free access to computers and wifi;

- free access to materials to learn English, and access to physical and online resources in other languages (Including Welsh in Wales);

- free activities and reading resources for children and families;

- trained workforce who can help with access to information and resources;

- community space to use for learning and networking;

- signposting to local education, health and wellbeing services;

- signposting to other Council services;

- signposting to community organisations and resources;

- tours of the library and all services offered (SCL Leading and Managing Public Libraries (2015).

In Scotland, the target number of Syrian refugees accepted via the Syrian Vulnerable Person Resettlement (VPR) Programme was set to 2,000 (10\% of the total number in the U.K) by 2020 . However, Scotland reached that target by the end of 2017, accepting one in five Syrians brought to the UK through the resettlement scheme. The new Scots (this is the preferred name for refugees in Scotland) integration strategy (2014 - 2017), which was developed as a partnership of the Scottish Government, COSLA (the voice of Local Government in Scotland) and the Scottish Refugee Council, addressed the needs of refugees as well as those seeking asylum, using the 1951 UN Convention relating to the Status of Refugees (Refugee Convention) and the supporting 1967 Protocol which defines a refugee as a person who:

Owing to well-founded fear of being persecuted for reasons of race, religion, nationality, membership of a particular social group or political opinion, is outside the country of his nationality and is unable, or, owing to such fear, is unwilling to avail himself of the protection of that country; or who, not having a nationality and being outside the country of his former habitual residence as a result of such events, is unable or, owing to such fear, is unwilling to return to it (Scottish Government 2017, p.2).

The purpose of the strategy was to coordinate the work of different organisations in this area in Scotland, creating active partnerships and ensuring that Scotland is a welcoming and supporting place for people who have experienced persecution and human rights abuses. This meant close communication and consultation with the refugee community and aligning strategic objectives with their direct needs, addressing health, housing, welfare rights, employability, education, community integration and social connections. Under this umbrella, The Scottish Refugee Council (SRC), offered the 'refugee integration' (RIS) programme which focused on supporting vulnerable Syrian families to address their initial critical needs. The 'New Scots: Integrating 
Refugees in Scotland's Communities 2014 - 2017 Final Report' (Scottish Government 2017) highlights a number of key achievements, including collating best practice approaches to supporting Syrian New Scots and establishing partnerships with a wide range of support groups. The Scottish Government also took the position that integration should commence not from when refugee status has been granted but from day one of an asylum seeker's journey. Therefore this effort also concentrated on mapping the services and support required during the asylum application process, which leading to informed and focused action (this was addressed via creating an Asylum Dispersal thematic group). There was also emphasis in the scheme on helping new Scots to become active members of Scottish communities, building their confidence and resilience and supporting them to gradually develop strong social relationships, considering that Syrian new Scot families encounter multiple challenges and family members have diverse needs (e.g. pregnant women, children, people with disabilities).

A second new Scots strategy 2018-2022 was published recently (Scottish Government, 2018) which aims to further support refugees and asylum seekers in Scotland's communities. The vision of the strategy is 'For a welcoming Scotland where refugees and asylum seekers are able to rebuild their lives from the day they arrive' and where Scotland:

- is a place of safety for everyone, where people are able to live free from persecution as valued members of communities;

- enables everyone to pursue their ambitions through education, employment, culture and leisure activities;

- has strong, inclusive and resilient communities, where everyone is able to access the support and services they need and is able to exercise their rights;

- is a country that values diversity, where people are able to use and share their culture, skills and experiences, as they build strong relationships and connections (Scottish Government, 2018).

COSLA provided a supporting and coordinating role to all 32 local authorities in Scotland in the Syrian VPR Scheme. The main indicators of integration included employment, housing, education, health, making social bridges, bonds and links in the communities, helping Syrian new Scots to develop language and cultural knowledge of their host country, ensuring their safety and stability and that they were aware of and were exercising their rights as citizens (COSLA, 2016).

The COSLA resettlement strategy included specific actions and milestones which addressed key points in the migration and resettlement experience of Syrian new Scots:

a) at pre-arrival ;

b) at the point of arrival;

c) up to the first month after arrival;

d) up to the first year of resettlement (COSLA, 2016).

\section{Research with Syrian new Scots}

The research project 'Lost in Information: Syrian new Scots' Information Literacy Way-finding practices' was funded by the CILIP Information Literacy Group (ILG). The aim of the project 
was to explore the information needs of 'Syrian new Scots', their habitual and adaptive information literacy practices and the barriers and enablers they encountered within their new socio-cultural setting via their interaction with people, tools and processes. The project ran from September 2016 to June 2017 and was conducted via interviews with three Local Authority Leads for Syrian Resettlement and focus groups with thirty-eight Syrian new Scots in three geographical locations in Scotland (which represented a mix of urban and rural locations). A drawing exercise that helped Syrian new Scots to discuss/elaborate on their main needs for information was used to enable creative communication about the participants' information world, and their experiences around seeking, receiving and communicating information. This approach helped to elaborate how and from where they received information, ways in which they shared information and how different people, things and circumstances could be presented as barriers or enablers in that process.

The progress and outputs of the research project during its different stages have been documented via the project blog (Martzoukou (2017). In addition, some of the key findings addressing information needs, barriers and the role of information in the newcomers' sociocultural adaptation have been published in Martzoukou and Burnett (2018). The research found that the everyday life information needs of Syrian new Scots and the sociocultural adaptation barriers they encounter are diverse. Some of these barriers are discussed below.

\section{Lack of English language skills}

One of the most significant barriers that the community of Syrian new Scots encountered was learning English. English language acquisition was a key to the integration of Syrian new Scots and the Home Office had addressed a number of requirements in relation to the provision of English for Speakers of Other Languages (ESOL) classes recognizing the centrality of English language support. For example, English language classes would be provided no later than a month after arrival, they would be at a level that was appropriate for the needs of individual people and they would be offered by an accredited provider. English language support would be provided different ways, delivered by Community and Development (CLDS), local colleges, voluntary sector partners and depending upon local differences and circumstances. There was also the recognition that developing a peer education pilot programme with the help of volunteers who supported learning was important (COSLA 2016).

However, the research found that although ESOL classes were provided, there were evident differences in the progress made by Syrian new Scots, with some progressing slower than others. This depended on a number of reasons:

\section{a) Age differences}

Learning English was perceived to be particularly difficult for senior learners who required additional support to help maximise their learning potential.

\section{b) Education}

Syrian new Scots had variant levels of education. Some had basic school education, whereas others lacked basic Arabic language reading or writing skills.

\section{c) Diverse previous life experiences}

Some people had been exposed to richer life experiences back in Syria (e.g. travelling, socialising, working abroad, and living in a large city as opposed to living within an isolated rural community) which made the process of developing new connections with people easier. 


\section{d) Different learning preferences/cultural differences}

Some people preferred more structured, traditional learning approaches within the class whereas others perceived peer-learning and involvement with the local English-speaking community as the most effective ways of learning conversational English which made them more confident in everyday life encounters with other local people.

Thus some Syrian families were learning faster and this also meant a faster integration into their host communities and gaining a sense of confidence, managing their family's matters independently. On the other hand, there were families who, despite being in Scotland for several months, still lacked confidence and were reluctant to attempt to communicate in English, progressing at a much slower pace and relying more on the support of their key workers. However, learning English was a significant priority for Syrian new Scots as it was directly linked to enabling progress with community integration and reducing feelings of isolation (Figure 1). English language was also important for securing employment opportunities and ensuring financial security, overall, helping them to address proactively and independently their own information needs and to solve everyday life problems.

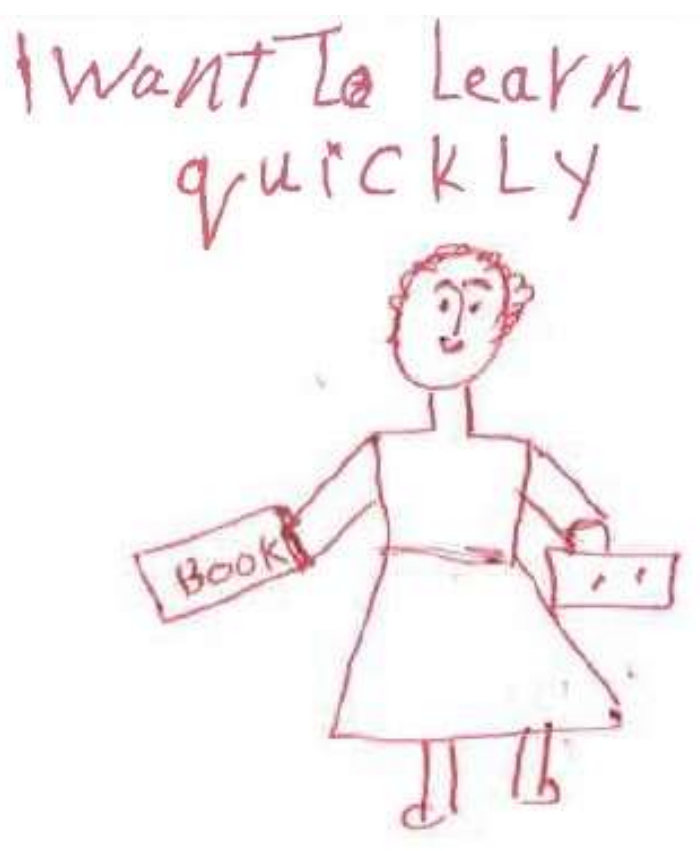

Figure 1 - Female participant demonstrating the importance of learning English quickly (translation by interpreter)

\section{Lack of financial security}

In line with the COSLA resettlement strategy, the local authority resettlement support service ensured that a bank account was opened for each Syrian new Scot family, when they arrived, and that they could withdraw money immediately. The Syrian new Scot families could access welfare benefits, social housing, healthcare and education services on the same basis as other citizens. However, the Syrian new Scots had financial concerns which were linked to longer term considerations. Male research participants, in particular, highlighted concerns which revolved around receiving support from the government in the future: 'If that stopped we would not know 
what we would do' (Syrian New Scots Focus Group Discussion). The slow transition from being a recipient of welfare services and benefits to an independent, self-reliant employee was an important on-going worry and a source of stress which became a barrier to integrating to their receiving society:

We are always thinking, we are very stressed, very worried. We are not enjoying life because of our worries, being stressed, always being stressed about this...this makes it hard to integrate. It's all an on-going worry (Syrian new Scots Focus Group Discussion).

A 'big obstacle', as put by Syrian new Scots, was the lack of English language and the lack of fast progress with learning, as explained earlier (Syrian New Scots Focus Group Discussion). In addition, having received refugee status, via the 'Syrian Vulnerable Person Resettlement (VPR) Programme', meant that many were not in a position to work because of serious health issues (which impacted them or a member of their family directly) or because of their previous experiences of severe violence and psychological trauma (Home Office, 2015).

The research participants had varied careers before the war. Some examples included car mechanic, joiner, electrician, decorator, art teacher, salesman, hotel owner and teacher of Arabic. A few participants had managed to find volunteering positions (e.g. working as a gardener, helping at a bakery). However, they were looking to be occupied with something they knew 'how to do, their career', utilising their previous expertise and knowledge (Syrian new Scots Focus Group Discussion).

In addition, Syrian families, who relied on benefits, experienced difficulties on the basis of addressing everyday additional expenses (e.g. the council tax, building maintenance expenses, the costs of electricity and other household bills). One problem that was mentioned particularly by people living within a rural area was transportation. Some of the basic needs of the families (e.g. hospital/job centre appointments and ethnic food shopping/halal food) were expensive activities as they required travelling regularly from a small town into the city. Because of the expenses of moving around, people were also less inclined to explore the local area, an issue which could have been addressed with a suitable transportation option or a fee reduction in the initial months of the resettlement process. As one of the research participants put it: 'the transportation for us is even more important than food. It's very very important' (Syrian new Scots Focus Group Discussion).

\section{Challenges with internet connectivity and ICT skills}

One of the most important priorities concerning technology when the Syrian new Scot families had first arrived in Scotland was Internet connectivity. There was a lot of support provided by the local community to ensure that the Syrian new Scots families had the basic means to connect to the Internet. For example, in one of the locations of the study, the local church had donated dongles and the university had donated PCs which meant that every family had a computer in the house and could get on the internet immediately. The Local Council Authority Leads for Resettlement had placed priority on Internet connectivity which was the only means the families could get in touch with their families displaced in other countries, such as Lebanon and Turkey. However, broadband or internet connection could not be organised straight away as the families did not have email addresses (which was also a barrier to paying utility bills, setting up bank accounts, and receiving health services such as repeat prescriptions). In addition, for some, email communication was considered to be a tool for business rather than a necessity for everyday life purposes.

Nevertheless, the local mosque had provided mobile phones with pay as you go mobile sim cards 
and these were used frequently for internet connectivity, especially in the first few days. Syrian new Scots used their phones as the basic means of communication locally and externally with their displaced families. In one of the locations of the study, a WhatsApp group had been set up for the families with the support of six or seven Arabic language volunteers who would help with translating. This was a helpful tool when it came to quickly translating important information, such as hospital appointments and, as most of that communication was kept in English, it offered opportunities for practicing conversational English. WhatsApp was also used by their families to communicate with displaced family members in different parts of the world. Although younger Syrians used additional apps on their mobile phones for navigating in town, for train and bus schedules and for translation activities, different age demographics were not a barrier to the basic use of mobile phones. A characteristic example was an older female who used different app to communicate with other Syrians, to get information from her peers and her teacher around English language lessons and to find answers for things she did not understand. She also often communicated with digital images, for example, the image of a rose to express gratitude when progressing with the English language class. Her 12 year old daughter was proactive in educating her in the use of technology. However, there was need for further support with classes for ICT literacy around the use of mobile apps and other useful online tools that would help the Syrian new Scots to effectively communicate, entertain their families, organise their everyday life needs (e.g. utility bills, hospital appointments), learn English and keep in touch with their families and friends.

\section{Family Separation}

As explained earlier, the COSLA resettlement strategy included specific plans for addressing everyday life needs in different stages of the integration process during the first year of Syrian new Scots' resettlement. Therefore, the Local Authority service had put together family integration plans with a checklist of key milestones that were to be addressed with the families; for example, registering with doctors' surgeries, for English language classes and with the job centre. However, emphasis was placed on understanding the families and catering for their individual needs as they had to deal with different and complex needs, ranging from addressing a disability or a terminal illness to reuniting with their families and children who still resided in another country, overcoming previous negative resettlement experiences in other host countries and addressing war related depression and post-traumatic stress after being a victim of torture or violence. An important issue was separation from their family members. Although most of the participants had extended families, some of their children, their parents or siblings were displaced in different countries (e.g. Syria, Lebanon and Egypt) and in some cases they had not seen them for years. These separation worries were illustrated via the drawings of participants (Figures 1 to 4 ) and in the participants' verbalisations: 'I hope we can all be together in one place. I miss my two girls' (Syrian new Scots Focus Group Discussion, female participant). In Figure 2, the participant drew on the left her two daughters, one in Lebanon and one in Egypt (names removed).

One of the other female participants had not seen her family and her son who was in Lebanon for two years. Another participant had not seen her family in Jordan for the past five years, nor had she ever met her grandchildren, who they were born in Egypt. Referring to two explosions in Lebanon, very close to where some of their families lived, they expressed how they felt that nowhere was safe: 'it is not safe in Beirut, it's not safe at all. Everywhere, it happened in Istanbul. It's not safe anywhere to be honest. Even here' (Syrian new Scots Focus Group Discussion). 


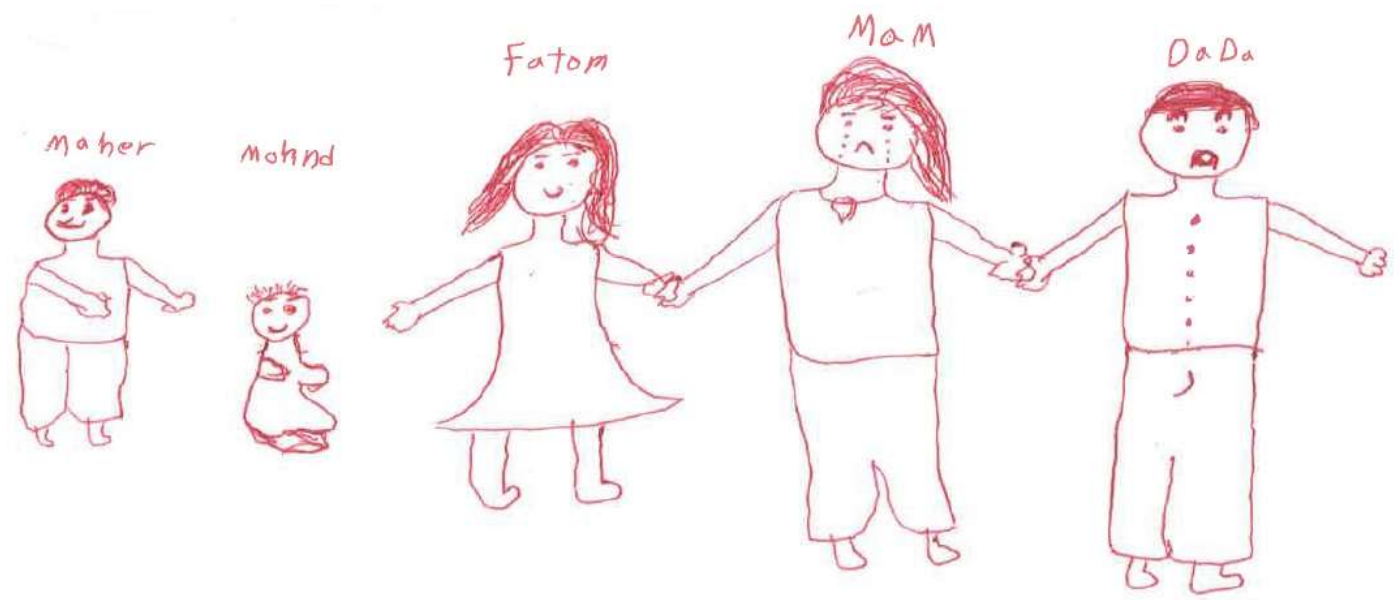

Figure 2 - A drawing depicting a female participant's family back in Syria

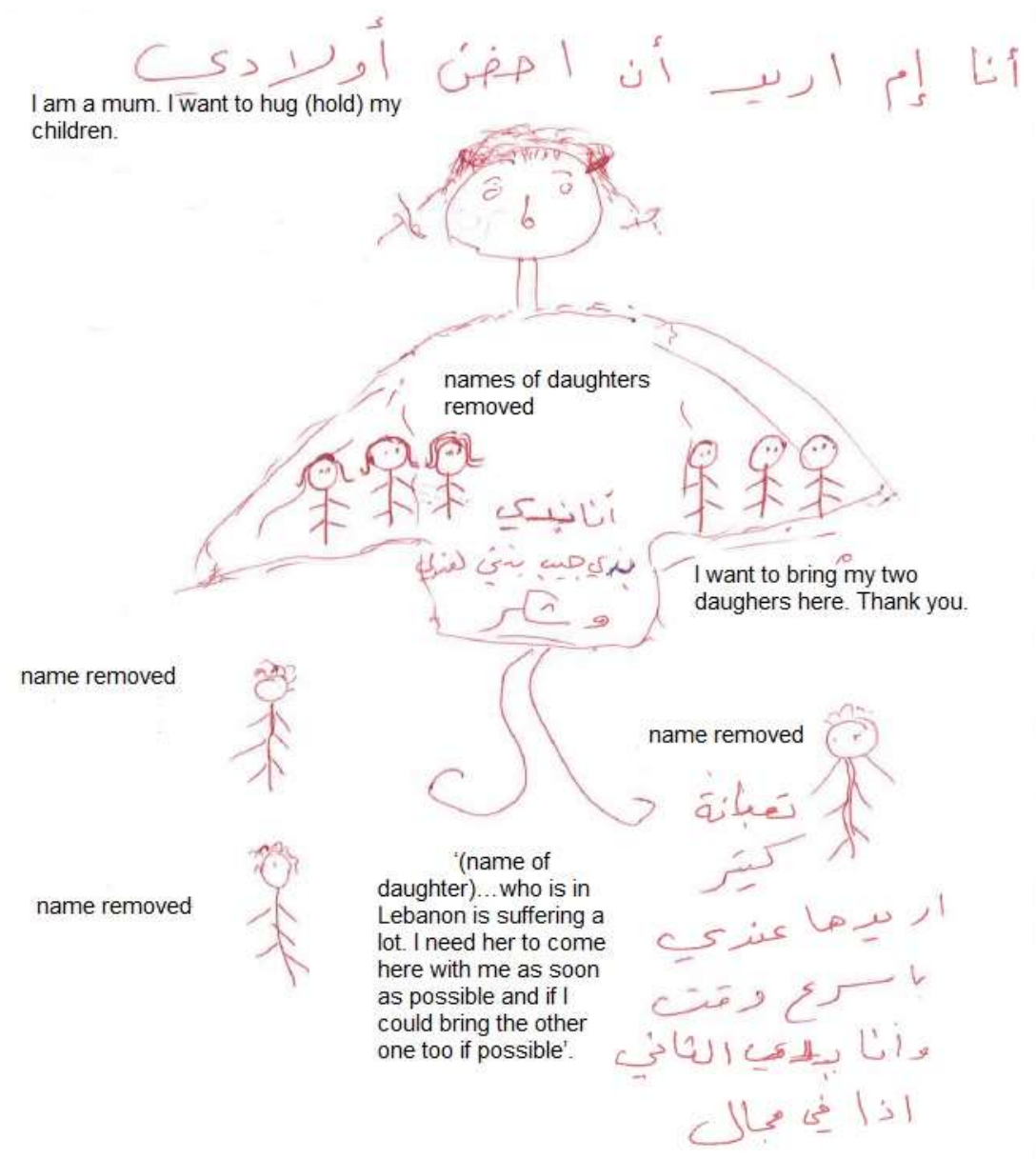

Figure 3 - A Syrian mother drawing herself holding her daughters and sons (names of children have been 

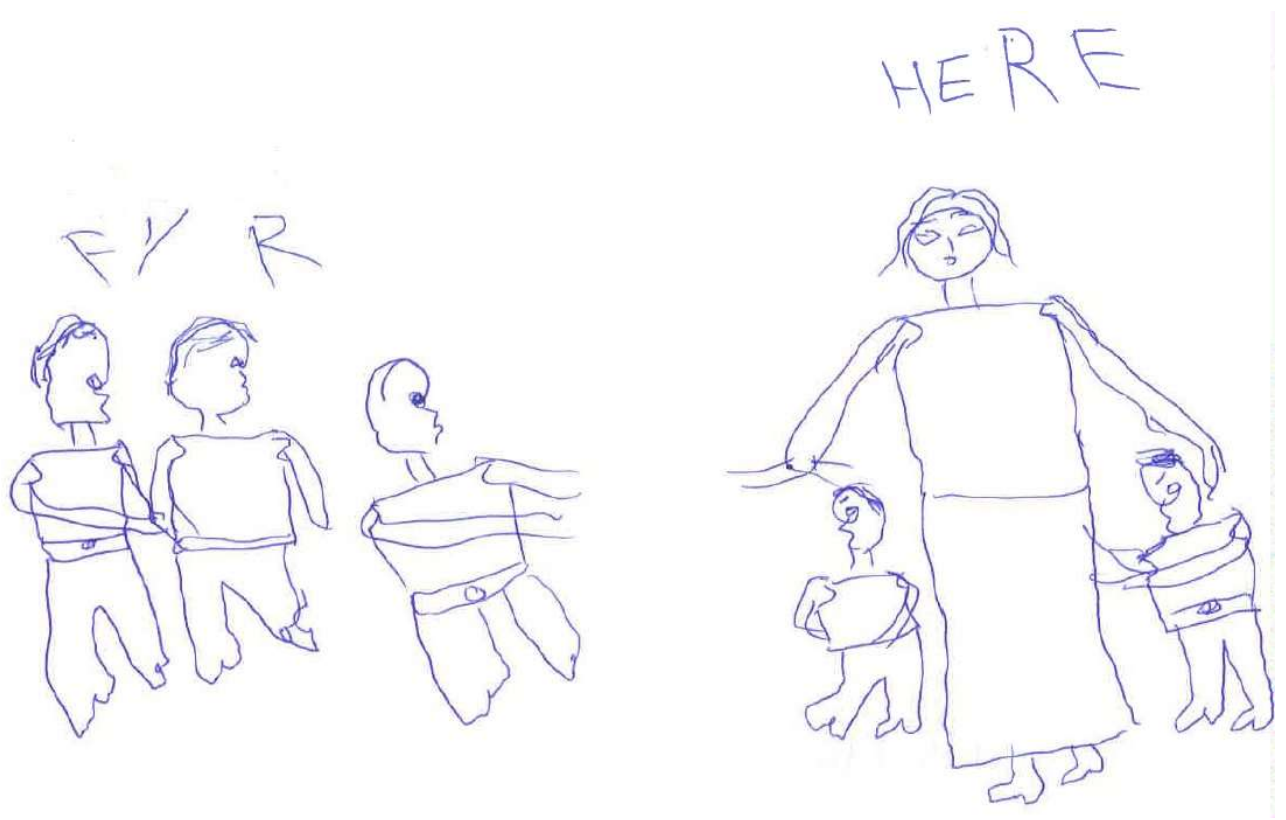

Figure 4 - A female participant drawing herself separated from her three children

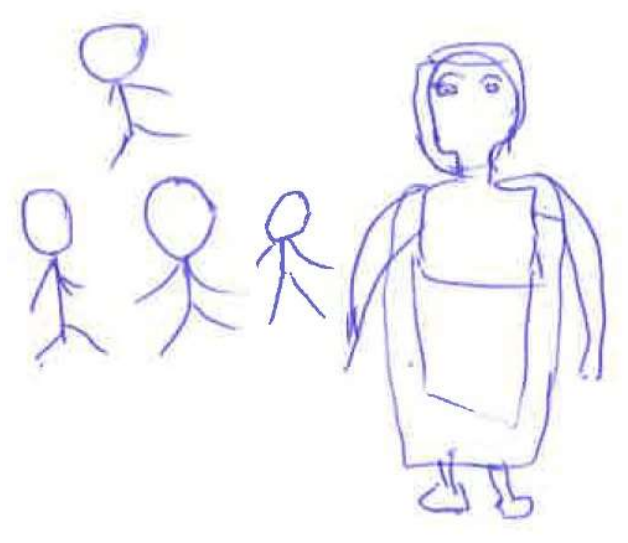

$$
\text { I Want my mom }
$$

Figure 5 - A female participant drawing herself separated from her child. 


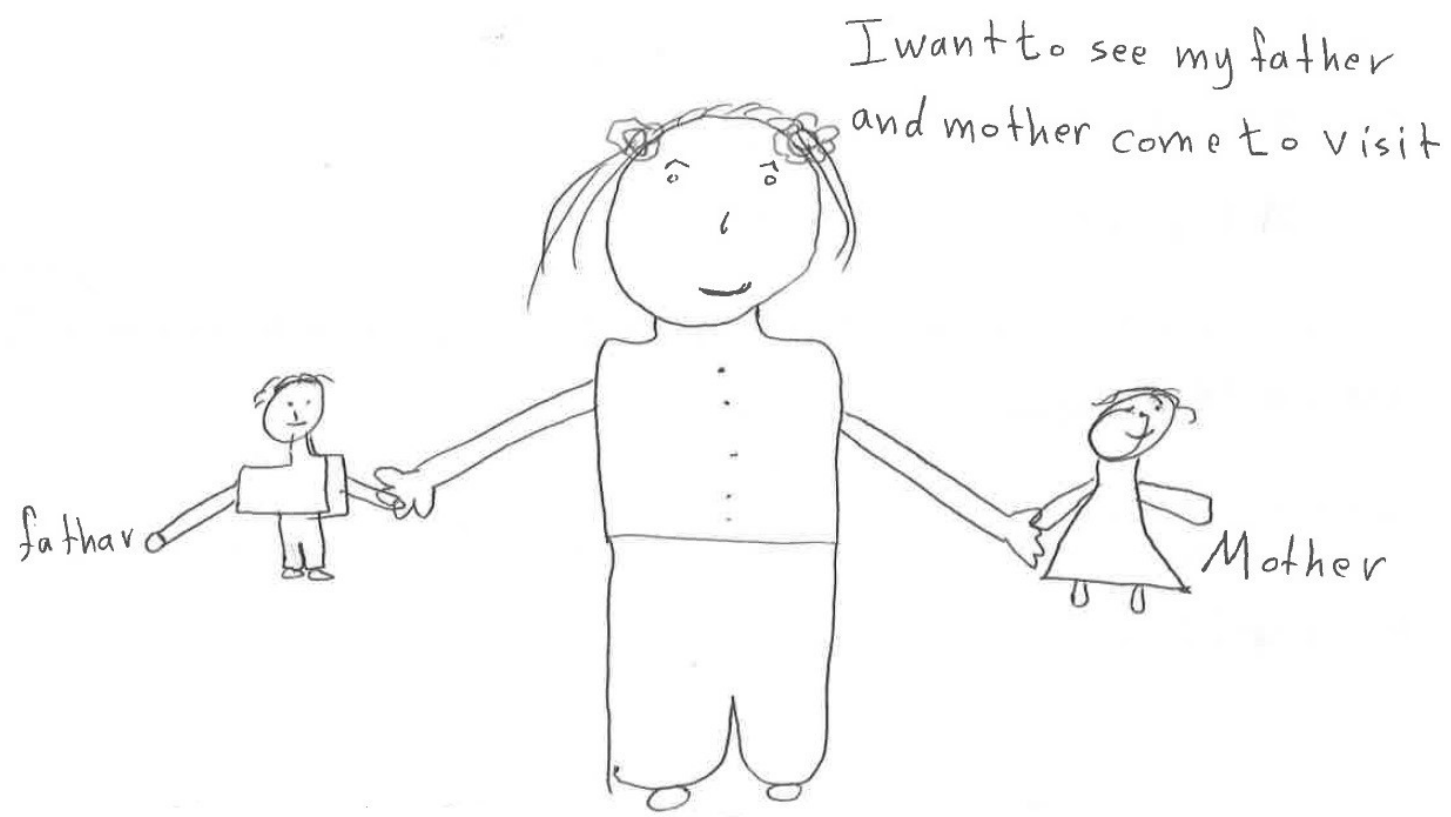

Figure 6 - A female participant drawing herself separated from her son.

The Syrian families had complex information needs around issues that concerned the possibility of being reunited with their displaced family members, for example what information they needed to know and what they should do for bringing them to Scotland, or their own eligibility for travelling to the countries to which they have been relocated. Out of the six children of one of the male participants, only his younger son was with him in Scotland and as he was experiencing health problems he was worried that he would not be in a position to take care of himself as his son was still very young:

...what worries me is the future; what is going to happen. Okay, we are adapting but what's next? ...Because we all have families elsewhere. Will we be able to have citizenship here? Will we be able to travel to visit our families elsewhere? Our families, will they be able to visit us here? (Syrian new Scots Focus Group Discussion).

There were different levels of vulnerability and family and health-related needs (Figure 7), which meant that there could not be a single approach for a homogenous group (Figure 3). Support, at least in the initial months of adaptation, needed to be tailored to individual family needs. This required building up capacities of knowledge and understanding and working closely with other partners (Local Authority Lead for Syrian Resettlement). 

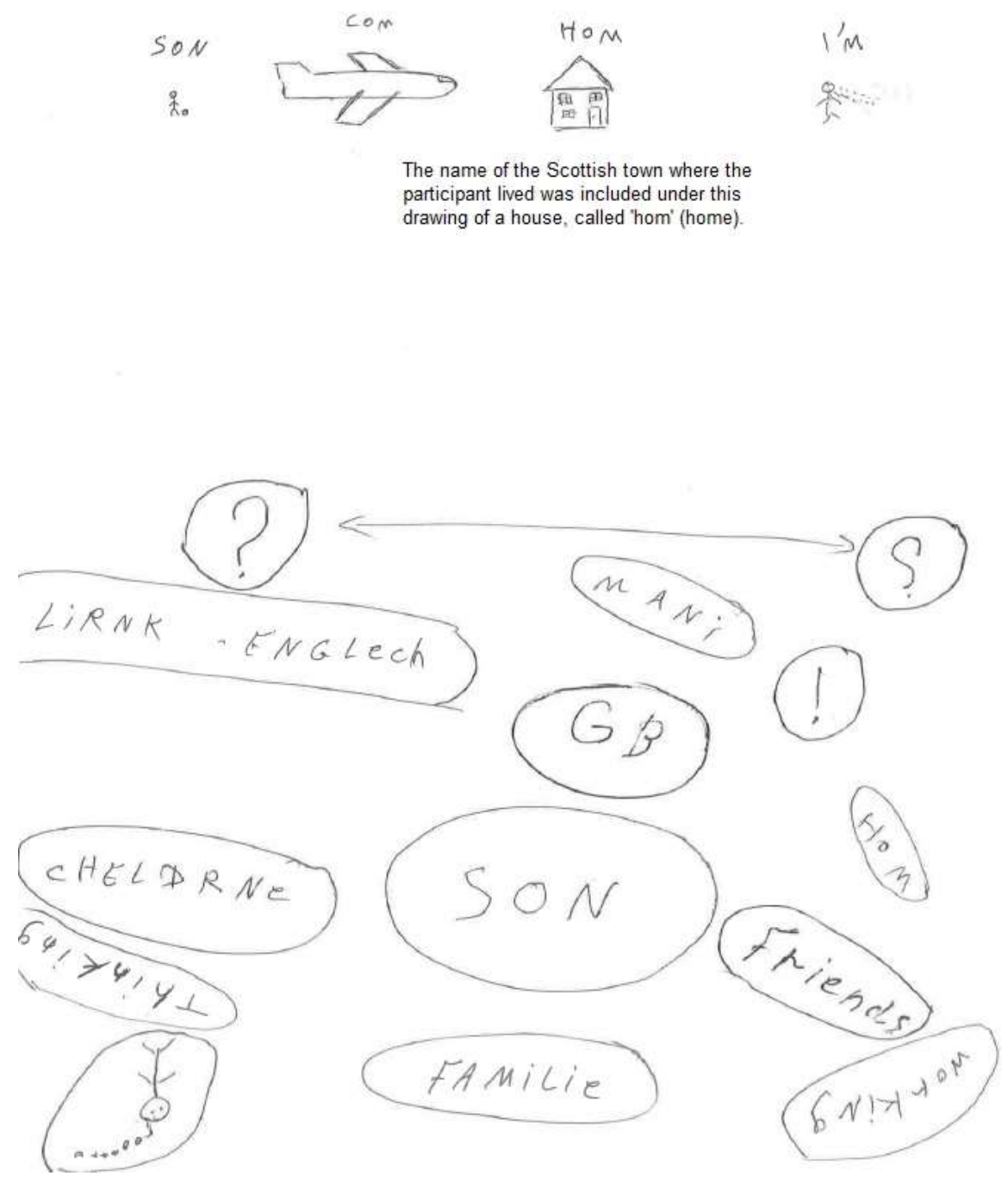

Figure 7 - Male participant's drawing depicting himself crying on the basis of concerns around family reunion, English language, financial security and integration

\section{Scottish Public Libraries support for Syrian new Scots}

The National Strategy for Public Libraries in Scotland 2015-2020 encompasses a vision and mission which sees Scotland's public libraries as 'trusted guides connecting all of our people to the worlds' possibilities and opportunities' and 'as part of a shared civic ambitions to fulfil the potential of individuals and communities (The Scottish Library and Information Council, 2015, p.3). Public libraries have the ability and potential to 'play a key role in improving access to opportunities for all of us including the most vulnerable' (p.11). Strategic aim 4, particularly, relates to the role of public libraries in Scotland 'contributing to social wellbeing, tackling social isolation, inequality, disadvantage, fractured communities and ill health'. According to this strategic aim, there are five main ways in which libraries can contribute to social wellbeing. These are:

- responding to the social needs of individuals and groups in their communities and developing activities and programmes to respond to particular needs; 
- making library space and support available for community interest groups and members of the community looking to support one another;

- contributing to the ability of individuals to become involved in their local communities and take part in local and national life;

- strengthening the identity and sense of community;

- creating a public service hub for the delivery of a range of public services (The Scottish Library and Information Council, 2015, p.25).

Therefore public libraries in Scotland encompass the vision of welcoming and helping vulnerable communities, such as refugees, embracing an ethos of social inclusion, nurturing their needs for learning, social well-being, community integration, helping to build capacity for active contribution of refugees to their host society, and enabling activities that create a sense of belonging for all. Public libraries are safe and welcoming spaces that are the heart and the central hub of the community as centres of readily accessible, free and useful information services to all members of society. This inclusive ethos means that libraries are ideally placed to contribute to improving the quality of life of vulnerable or excluded groups such as asylum seekers and refugees and help them to integrate into existing communities.

As part of the Syrian new Scots' research project, the role of the local public libraries and their existing support were explored, placing emphasis on the potential of transforming the library into a trusted 'third' place for Syrian new Scots, "a place where people choose to go that is outside of their work or home". In that way "the library can become the "third place" giving them a place to meet and create a sense of community" (Montgomery and Miller, 2011, p.232). Two areas specifically were addressed: public libraries' role in helping Syrian new Scots to develop English language and ICT skills, and their emerging role as community centres helping in the social integration of Syrian refugees, supporting them to address everyday life information needs (e.g. health, housing, rights and entitlements, job seeking).

In one of the locations of the research study, it was clear that during the first few days in Scotland almost no-one had considered the library as a place for connecting to the internet or for borrowing resources for learning English. When the Syrian new Scots had initially arrived, they felt that the public library was not the right place to visit. Women in particular felt that they were visibly differently dressed and, at the initial phase of resettlement, 'things were a little too intense so it wasn't a priority' (Local Authority Lead for Syrian Resettlement). In addition, neither the Syrian families nor their local support services used the word 'refugee'. The families were Syrian new Scots and 'refugee' was perceived as a process they were going through: 'it's part of their identity but it's not something they want to be associated with':

On the first day some of the people were really keen to talk about how people see us. They've obviously following the media, they are following the thing about the UK, understood a lot about how things were changing in Europe and how they are going to be perceived...they didn't want to be refugees" (Local Authority Leads for Syrian Resettlement).

However, after the first few months, Syrian new Scots were more open to using the library. For example, one of the female participants from the urban location had a library card she used to borrow books, mainly in Arabic language (and she indicated that she could find quite a lot of variety). She also borrowed books to help her with English although she found that learning that way was 'very difficult and complicated'. On the other hand, other people felt that there were not 
sufficient Arabic resources available (for example there were more in other languages, such as Polish). One of the Local Authority Leads for resettlement felt that if there was a specific Arabic resource and if every library had guaranteed a hub and the families had received that information, they would have been more likely to use to the library more extensively. In addition, the presence of Arabic speakers in the library would motivate people to visit it more.

Overall, access to the library differed locally. For example, Syrian new Scot families, who had been placed in the urban location, found it difficult to gain the confidence required to use the bus to visit the city centre, especially in the first months and until they felt more able to communicate in English. As explained earlier, the use of transportation was also an important financial consideration. On the other hand, the families who had been placed in the rural location had easier access to local facilities including the library, as these were closer and within walking distance. A distinctively different approach was also followed for the rural component of the study, where the library was situated within the community building and where local services to the Syrian new Scots families were offered together with a range of social activities. Access to the library was easier for the families. The library worked in partnership with the ESOL service and the English language classes were held in the rear of the library, so the families familiarised themselves with everything that happened in the library area. The Local Authority Leads had worked in partnership with the library as part of the strategic and operational plan before the families had arrived. The library had invested money in dual language story books for children and had ordered them before the families arrived (although they did not know the ages of the children so they had tried to address needs at various levels).

The library also organised mother and toddler groups (put together with the help of a volunteer who brought books for the children) to encourage parents to take their children into the library at an early age. There were a small number of the mothers who were going to these weekly sessions. Participants in that location mentioned using the library for a number of different purposes, e.g. borrowing books in both English and Arabic, using the Internet and attending the toddlers' rhyme time group at the library. One female participant had been referred to early years' sessions by her midwife (demonstrating how that partnership had extended beyond the council, ESOL and the library to the NHS).

The library was also keen to attract new potential volunteers to see the work with the existing volunteers and the Syrian new Scots families. This was very valuable as it encouraged other Syrian families to come forward as potential volunteers themselves. This was a crucial emerging role for the public library on the basis of offering not only library space where activities for learning English and other classes could be organised, but also for increasing awareness in the local community. Having already been through the initial phases of the integration process and becoming increasingly more confident and independent, Syrian new Scots themselves could play a significant role in the integration of new arriving families. All the Syrian participants were positive about helping others, communicating with them and sharing their experiences as much as possible: 'whatever we could do, we would do anything'. However, they would not just offer new families their experiences; they would 'relate' their experiences, 'show them around the town, the shopping, the centres. Show them the basics, how to get by, how to deal with the health centre and transportation' (Syrian new Scots Focus Group Discussion).

One of the Syrian new Scots had already offered to become a volunteer coordinator, offering support to the next arriving families; he was expected to have a recognized role and be a formal part of the team offering an insight into what is important and that will be challenging for the integration of the families. The importance of this contribution was beyond a simple information 
provider role. It would offer value to community development as the families would not just 'become a guide to information but they become part of the social integration' (Local Authority Lead for Syrian Resettlement). Similarly, another participant who was an Arabic language teacher, was very interested in helping with the integration of Syrian refugees who were illiterate in Arabic and with overcoming the initial communication barriers of. A few months after the focus group interviews, a young Syrian new Scot had already set up a local group which aimed to help with the integration of new arriving families. The group had plans to organize a number of events that would bring people together (e.g. coffee mornings). One of the first more formal support activities in which the group had started to get involved with, was also a peer English language learning programme which had been developed in response to the Resettlement Programme (of Syrian refugees to Scotland). The programme had put together a working group of peer educators selected from refugee families and local community volunteers with the aims of learning English, building social connection and exchanging cultural experiences via a number of formal or informal social activities that would be organised in the local community (e.g. women's walking, smoking cessation, making new memories). Therefore, there were important roles for Syrian new Scots who had already been through the first phase of integration (i.e. they had been in Scotland for several months and felt more familiar with how their new environments were structured and what support they could provide to the new families).

\section{Case studies of Public libraries in Scotland supporting Syrian new Scots}

Some of the work that public libraries have developed to support refugees in Scotland has been documented via the Network (2017) website, which is a network of local authorities (public libraries, archives and museums) in England, Wales, Scotland and Northern Ireland, national museums, archives and libraries, university departments, professional bodies (such as CILIP), heritage organisations (including English Heritage; the Heritage Lottery Fund), charities, voluntary sector organisations (including the National Literacy Trust) and Individuals committed to tackling social exclusion.

However, the majority of the projects reported on the Network have been based in England and with a focus on refuges in general. A systematic effort to put together information on Scottish public libraries' contribution to Syrian new Scots in particular, is not readily available and this means that a lot of the excellent work that public libraries do in this area is not formally documented. 'Lost in Information: Syrian new Scots' Information Literacy Way-finding practices' project sought to initiate this process by collating examples of good practice in selected local communities, via a call to showcase public library support, resources, projects and activities aimed at Syrian new Scots. Although the examples presented below from different Scottish geographical areas, who responded to the call, are not representative or necessarily typical of the present picture, they offer a starting point for further information sharing and exchange of ideas.

\section{North Ayrshire Council libraries}

Prior to the arrival of Syrian new Scots in North Ayrshire, North Ayrshire Council libraries met with Housing, Education and Community Learning colleagues to establish how many Syrian new Scots were expected, where they would be housed, and find out more about the demographic characteristics of the expected families (e.g. children of school age). Based on these discussions, the libraries bought a collection of Arabic books (e.g. children's books, short stories collections and dual Arabic/English language recourses) and placed them in the library nearest to where the new families had been housed. The libraries are also considering offering meeting spaces in the libraries and recruiting Arabic speaking Computer Buddies and BookBug leaders. 


\section{Rothesay library, Isle of Bute}

In September 2015 Argyll and Bute agreed to resettle 20 Syrian refugee families through the Home Office's Syrian Vulnerable Persons Relocation Scheme. Since then additional families have been resettled:

The Refugee Resettlement Group was formed under the banner of the Community Planning Partnership with membership from both Council services and partner agencies. Members included housing, education, adult learning, health and social work, benefits, Business Gateway, communications, ACHA, Fyne Homes, Police Scotland, Scottish Fire and Rescue, DWP and from the third sector Bute Advice Centre, Carr Gomm and Argyll and Bute Third Sector Interface (TSI)' (Argyll and Bute Council Council Community Services, 2017).

The library extended a warm welcome to the Syrian new Scots who arrived to the island and has several Syrian library members. The library holds Arabic leaflets in its MCISS (Macmillan Cancer Information and Support Service). Popular services with the Syrian new Scots families, when they first arrived, were the library's guest free Internet wi-fi access offered via the 'Peoples Network' programme, before gaining access to these facilities at home. The Adult Learning team invited female Syrian new Scots to library to introduce Community-based Adult Learning services and classes which include how to keep up with new technology, take the first steps into learning, enjoy community life more fully progress into further learning and gain skills to find work. The library has a collection of children's and young adults' books in Arabic and several Syrian children come to the library during school visits. The library also offers a venue for English Language Classes in the Adult Learning office or in the Greet Tree Room (Moat Centre).

\section{Aberdeenshire libraries}

The first Syrian new Scots families arrived in Aberdeenshire in February 2016. Since then additional families were resettled via the Home Office's Syrian Vulnerable Persons Relocation Scheme undergoing a programme of integration. An initial meeting was held in Inverurie Library on how Aberdeenshire libraries could support the Syrian new Scots Aberdeenshire classes. Following that meeting, a number of community and learning events were organised for Syrian new Scots in close collaboration with a local charity organisation, 'Al Amal' set up by a group of young Syrian new Scots to raise awareness about the Syrian new Scots in the local community; and help new families gradually integrate to their new society with the help of Syrian new Scots who have already been via the process of initial integration, putting emphasis on the value of peer support. The mission and vision of 'Al-Amal' (which means 'hope') is set on the following priorities:

- to improve resettlement experiences by enabling Syrian families to contribute to the planning, operational and evaluative process;

- to reduce isolation, low mental health, boredom and frustration by encouraging active community participation;

- to develop community projects that build on the skills, knowledge and expertise of Syrian new Scots;

- coordinate and work with other groups with similar objectives;

- to develop employability skills and learning; 
- to raise funds for cultural trips and experiences;

- to enable Syrian new Scots to support community events and projects locally;

- to develop the use of Social Media to aid communication;

- to advocate for the unmet needs of Syrian new Scots locally.

The Syrian families resettled in Aberdeenshire were keen to have ICT classes within the library to help with their resettlement within the area. They were also interested in having Bookbug sessions solely for Syrian families to allow women to come along without fear of being in the company of men. The Information Literacy and Learning Librarian for Aberdeenshire libraries, Ms Jacqueline Geekie, was tasked with appointing an ICT volunteer from the group of young Syrians. Although the library normally provides one-to-one support, the Syrian new Scots were keen to have a class for several students; this worked better than the usual format and could be taught by the Syrian volunteer in a self-sufficient way. The introduction of these classes caused a huge interest on the Al Amal WhatsApp group with 15 participants signing up to attend the classes. The class took place in the library on a Saturday afternoon when the computers were booked for the group to use. The most suitable topics selected were computer basics; email; shopping online including an overview and how to shop from Amazon, eBay, and some of the sites. The tutor was open to adding in anything else they would like to learn. However soon after the classes began it became apparent that, as well as ICT help, the group required their English to be improved. The library was asked to purchase Arabic keyboards to allow the students to pick out the English letters on the keyboard. These are now available in the Inverurie library and can be requested when required.

As part of 'Book Week Scotland 2017', Aberdeenshire libraries organised an event in Inverurie Library with the 'Al Amal' group to share the culture of the Syrians and a little of their story coming to Scotland. The theme of Book Week Scotland 2017 was Nourish and one of the strands was called 'Breaking Bread' and was about sharing culture. The 'Al Amal' group created a film which they shared with the community to explain about their homeland. It was a very powerful evening which was fully booked and helped to integrate the Syrians even more into their community. There was a definite feeling of wanting to help and encourage, and the 'Al Amal' group thanked the communities for the welcome they received.

Future Plans of Aberdeenshire Libraries involve continuing using the format they have already used during Book Week Scotland and organise similar events in the libraries in each of the communities where Syrian families have settled. These events will include Syrian food which will be supplied by 'Al Amal'.

\section{Aberdeen City libraries}

A pop-up Learning Space was created in Aberdeen Central Library in 2017, to accommodate up to 10 Syrian learners and a tutor for ESOL classes. The classes ran twice weekly, a men only class and a women only class, hosting approximately 7 learners in each. This was set up to help solve issues surrounding childcare. Due to the success of the classes the bookings were extended into 2017/18, consisting of four classes per week, two classes for men and two for women, each lasting for one and a half hour.

Additionally, Aberdeen City Libraries developed digital support for Syrian new Scots, working closely with the Adult Learning Team. A computing class was established in the Central Library in 2017 which is open to all ESOL learners and the people in the Syrian learner groups were 
invited to attend. ESOL tutors working with the Syrian learners classes are now also making use of these computer facilities, adjacent to the Learning Space, to support both their language skills and their everyday life skills, for example, using software such as the learner driver, Theory Test Pro.

Aberdeen City Libraries have offered support with reading and both and Syrian new Scots have been given tours of the Central Library. Many of them (both female and male) have now joined the library and are active members, borrowing both English and dual language books to read individually and/or with their children. Library staff are working closely with the ESOL tutors as part of the stock selection process to ensure there are appropriate resources available to the learners at the correct levels to support and encourage progression in their reading and learning.

Feedback from the ESOL tutor has expressed thanks for creating an 'effective learning space in the library, for my Syrian classes'. For example, following the tour of the library by the men's class, the tutor contacted the library staff to say: 'What a joy to see learners walking out with armfuls of books!' As the tutor put it, 'It's about confidence and breaking down barriers, opening up access for them where before things were inaccessible simply because they didn't know all the fabulous stuff that was available to them or had no idea what they had to do to get it, or insufficient confidence to try in case they got it wrong or misunderstood something crucial'.

\section{Discussion and conclusion}

Public libraries have been actively developing projects and activities to support the needs of refugees (and asylum seekers). They have been for long connecting to their refugee and asylum seeker communities coming from diverse ethnic backgrounds. For example, 'Welcome to your Library' (WTYL) (2007) was a project which took place from 2003- 2007 funded by Paul Hamlyn Foundation and co-ordinated through London Libraries Development Agency, with the aim of connecting public libraries with refugees and asylum seekers. The foreword by the Chair of London Libraries Development Agency places emphasis on public libraries as 'one of the very few services that anyone can access freely, irrespective of status or money. And because libraries act as gateways to civic presence, with the library card as an easily accessible symbol of citizenship' (p.v). The project case studies demonstrated examples of library services beyond the provision of information to actively involving the refugee communities in practical activities (such as discussion groups and 'conversational clubs', citizenship activities) emphasising the need for moving 'from delivering services to people and towards delivering services with people'. Public libraries play a significant role as central spaces for accessing information and recourses for diverse learning, recreational and creative activities, bringing the community together, encouraging people to engage and interact with each other on a local level. Designing active programmes which help the refugee communities to develop and enhance their existing skills and make a more direct contribution to their local community, through engaging them in service delivery locally is vital (for example, by means of engaging refugees and the local community in local events that celebrate different cultures and encourage cultural heritage exchange, or by sourcing support to newly relocated refugees from the local refugee community) In addition, raising awareness of the issues that refugees are facing as well as an understanding of social inclusion barriers, in general, is crucial and this could be enabled via staff development programmes. Finally, the project stressed the importance of promoting the contribution and role of public libraries to the wider policy context and contributing to cross-sectoral agendas via diverse partnership development beyond the library sector. 
In our research, we, similarly, found that supporting Syrian new Scots to become more independent and proactively involved with the community helped them increase their confidence in navigating their new information environments, interact with the local community and regain a sense of normality. Organising social activities helped Syrian families to build social and emotional bonds with other local Scottish families more directly, and helped them to create reciprocal contributions on the basis of their already existing knowledge and skills. However, with lack of English, in the first year, the provision of bilingual resources on their own was not sufficient. There was the need for on-going commitment of bilingual support either from the volunteering or the Syrian community which was fundamental for building trust and bridging communication barriers in a more direct and purposeful way. Based on the research findings of the 'Syrian new Scots' Information Literacy Way-finding practices' and via additional consultation with a number of other key stakeholders, a number of key recommendations on ways in which public libraries could further support and enable Syrian new Scots to adapt to their local communities, feel a sense of belongingness and successfully establish their identity into the Scottish society have been put forward as following:

- establishing a single library card for Syrian new Scots and automatically signing families as members;

- $\quad$ setting up a community hub with volunteering \& working opportunities for Syrian new Scots;

- providing health information in accessible pictorial formats;

- helping Syrian new Scots to develop their health \& digital literacy (via the provision of additional classes);

- offering source material in Arabic (including newspapers and material for children) / Arabic speaker volunteers based in local public libraries;

- $\quad$ setting up family sessions and getting Syrian new Scots to engage additionally with the early years programme;

- creating a friendly, welcoming and trusted 'third place' for families to learn, socialise and feel part of the community (e.g. by introducing induction sessions and a short film on what public libraries could offer).

Public libraries in Scotland have already put some of the above plans into action. However, greater and more systematic visibility of their contribution is required to showcase their impact and additional collaboration within the library sector that will enable greater capacities. For example, one of the recommendations of the 'Welcome to your Library' (2007) project was for creating a central, nationally coordinated 'information hub' for sharing resources across the entire library sector for the purpose of developing engagement activities. These may include volunteering and working opportunities for Syrian new Scots which may create social capital for their hosting communities. Staton (2017) has described how the movement of refugees into cities 'could become a positive part of urban life...spurring population growth and economic development' if the bureaucracy 'which often hampers efforts to get refugees into work' is reduced. For example, in Sweden the government has encouraged new arrivals into work, via a fast-track to employment programme, called Snabbspåret - the programme matches refugees with jobs in sectors where there is a shortage of workers, offering training and mentoring. Another example includes a group of Syrian refugees in the Netherlands who have joined efforts, with the support of a social inclusion programme, to recycle thousands of lifejackets abandoned 
on Greek beaches into commercial items (e.g. laptop bags and flags) (Holligan, 2018). The 'Makers Unite' organisation, explores participants' talents, supports them to develop entrepreneurial skills and introduces them to educational training, internships and employment opportunities.

Libraries in Scotland could play a key role in their local communities by enabling capacities in partnership with other external organisations and the voluntary sector via diverse partnership projects related to support for health, everyday life, citizenship, skills and employability. For example, for supporting Syrian new Scots with their employability, public libraries could join forces with a number of services, e.g. Careers Scotland (part of Skills Development Scotland) offering career guidance and advice about becoming more employable; Job Centre Plus (the UK government website with links to Universal Jobmatch Service and employment advice); Volunteer Scotland (the national website for finding volunteering opportunities across Scotland); and Bridges Programmes, which is a specialist agency in Scotland supporting the social, educational and economic integration of refugees, asylum seekers, migrants, and anyone for whom English is a second language in Glasgow. Scottish Libraries could also work in partnership with key local organizations that offer volunteering opportunities, such as Volunteer Glasgow, Volunteer Edinburgh, the Wise Group as well as work closely with local colleges and universities to offer employability and skills training.

As eloquently put by Amina Shah (2016), Director of Programme at The Scottish Book Trust, during 'Scotland's Libraries: Inspiration for the Nation' Campaign:

Those of us who work in libraries and with books...should shout as loudly as we can about the fact that libraries are not just nice to have - not a peripheral luxury, but the absolute bedrock of a democratic society; of one that believes in investment in preventative measures and in giving everyone equal access to information, books, space and time to live an empowered and informed life and a real answer to reducing poverty, inequality and the attainment gap.

Scotland's public libraries are developing into 'trusted guides' connecting Syrian new Scots to the possibilities and opportunities created within their new communities and their role in welcoming refugees can be further empowered by maintaining close partnerships with key organisations who directly support refugees' social wellbeing, health, employment opportunities and their overall societal integration. The European Bureau of Library, Information, and Documentation Associations (EBLIDA) (an independent umbrella association of library, information, documentation, and archive associations and institutions in Europe), supports the notion that 'libraries all over Europe should act as a platform for democratic and open-minded values, and be a safe place where social inclusiveness for all is a priority' (EBLIDA, 2015). Public libraries in Scotland have embraced this strategic agenda with impactful work to support Syrian refugees in their local communities and are developing further services which, with close partnerships, could make a real difference in the lives of Syrian new Scots and the communities which have welcomed them.

\section{References}

Argyll and Bute Council Council Community Services (2017), Year 2 Evaluation of The Argyll and Bute Refugee Resettlement Programme, 30 November 2017, https://www.argyllbute.gov.uk/moderngov/documents/s121810/Year\%202\%20Report.pdf . 
Bridges Programmes, http://www.bridgesprogrammes.org.uk/.

Brokenshire, J. (2016) Refugees and Resettlement: Written statement - HCWS687, 21 April 2016, https://www.parliament.uk/written-questions-answers-statements/writtenstatement/Commons/2016-04-21/HCWS687).

COSLA (2016) Scottish Local Authorities and the Syrian Vulnerable Person Resettlement Scheme. Teaching ESOL to Refugees Event. Glasgow, Monday 29 February 2016, https://education.gov.scot/improvement/documents/cld17-cosla-esol-event.pptx.

EBLIDA (2015), Press Release: Public Libraries in Europe Welcome Refugees, 21 September 2015, http://www.eblida.org/news/press-release-public-libraries-in-europe-welcome-refugees.html

Holligan, A. (2018) Refugees in Amsterdam giving lifejackets a new life, BBC News 12 May 2018, https://www.bbc.co.uk/news/av/world-44086942/refugees-in-amsterdam-giving-lifejackets-anew-life).

Home Office (2018a) Immigration statistics, October to December 2017 second edition. How many people do we grant asylum or protection to? https://www.gov.uk/government/publications/immigrationstatistics-october-to-december-2017/how-many-people-do-we-grant-asylum-or-protectionto\#resettlement.

Home Office (2018b) Migration Statistics.

https://www.gov.uk/government/collections/migration-statistics\#data-tables).

Home Office (2015) Syrian vulnerable person resettlement (VPR) programme, www.gov.uk/government/uploads/system/uploads/attachment_data/file/472020/Syrian_Rese ttlement_Fact_Sheet_gov_uk.pdf .

Makers Unite (2017), Our Story Connecting people by making products with a story that matters, https://makersunite.eu/mu-story/.

Martzoukou, K. (2017) Lost in information? Syrian new Scots' information literacy way-finding practices, https://syrian-information-literacy.blogspot.co.uk/2016/09/

Montgomery, S.E. and Miller, J. (2011) The Third Place: The Library as Collaborative and Community Space in a Time of Fiscal Restraint, College \& Undergraduate Libraries, Vol. 11 (2-3), pp. 228-238,

https://www.tandfonline.com/doi/full/10.1080/10691316.2011.577683?scroll=top\&needAcces $\mathrm{s}=$ true

Shah, A. (2016) Scotland's Libraries - Promoting the Value of Literacy and Learning. Inspiration for the Nation 2016, The Chartered Institute of Library and Information Professionals http://www.cilips.org.uk/scotlands-libraries-promoting-value-literacy-learning/ .

Staton, B. (2018) How Sweden Is Fast Tracking Refugees Into The Workforce, Fast Company, 28 July 2017, https://www.fastcompany.com/40446055/how-sweden-is-fast-tracking-refugeesinto-the-workforce.

SCL Leading and Managing Public Libraries (2015) Library leaders across England and Wales confirm the welcome offered to refugees and asylum seekers from public libraries, 25 September 2015, https://ascel.org.uk/sites/default/files/uploads/public/Libraries\%20extend\%20welcome $\% 20$ to \%20refugees $\% 20$ and $\% 20$ migrants.pdf.

Scottish Government (2017) New Scots: Integrating Refugees in Scotland's Communities 2014 - 2017 Final Report, http://www.gov.scot/Publications/2017/03/5825.

Scottish Government (2018) New Scots Refugee Integration Strategy 2018 - 2022, http://www.gov.scot/Resource/0053/00530097.pdf. 
Scottish Refugee Council, (2016), Lest We Forget: WWI - Refugees Then and Now, http://www.scottishrefugeecouncil.org.uk/what we do/arts and cultural activities/lest we fo rget

The Network. Tacking Social Inclusion in Libraries, museums, archives and galleries (2017), http://www.seapn.org.uk/about

The Scottish Library and Information Council (SLIC) (2015) Ambition \& Opportunity: A Strategy for Public Libraries in Scotland 2015-2020, https://scottishlibraries.org/media/1133/ambitionopportunity-scotlands-national-public-library-strategy.pdf

The Wise Group (2018), https://www.thewisegroup.co.uk/

Vincent, J. (2015), Welcoming Refugees to the UK (and to Libraries), CILIP The Library and Information Association, 30 September 2015, https://archive.cilip.org.uk/blog/welcomingrefugees-uk-libraries

Volunteer Glasgow (2018), http://www.volunteerglasgow.org/

Volunteer Edinburgh (2018), https://www.volunteeredinburgh.org.uk/

Welcome To Your Library: connecting public libraries and refugee communities. Evaluation Report. November (2007). ADP Consultancy, http://www.seapn.org.uk/uploads/files/WTYLEvaluationReportrevisedversion.pdf 